PENGARUH MOTIVASI KERJA, KEPEMIMPINAN TERHADAP KEPUASAN KERJA KARYAWAN SERTA DAMPAKNYA PADA KINERJA PERUSAHAAN

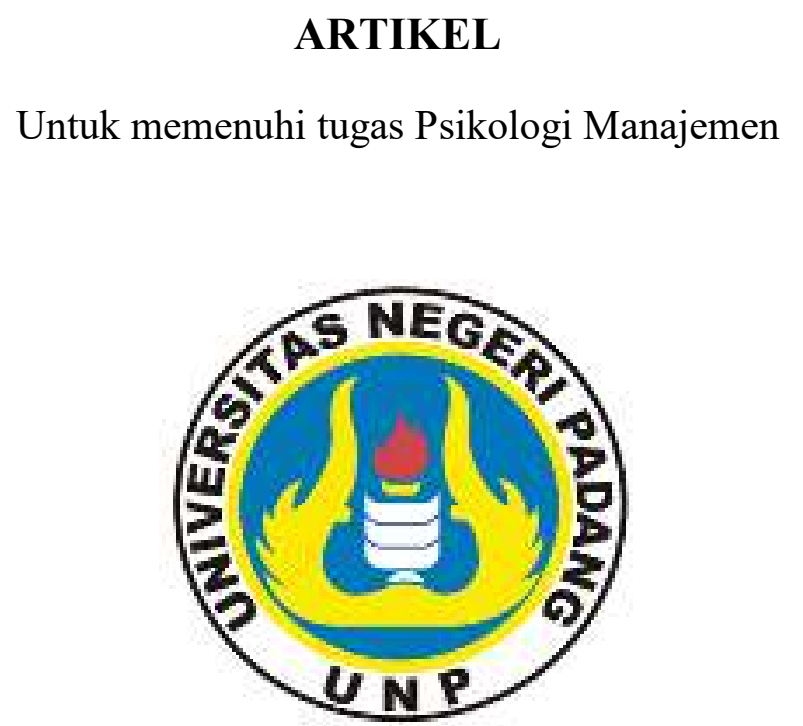

Disusun oleh:

Maulidatul Fauziyah 17002131

Dosen Pembimbing:

Dra. Ermita, M.Pd.

ADMINISTRASI PENDIDIKAN

FAKULTAS ILMU PENDIDIKAN

UNIVERSITAS NEGERI PADANG 


\title{
Pengaruh Motivasi Kerja, Kepemimpinan Terhadap Kepuasan Kerja Karyawan serta Dampaknya pada Kinerja Perusahaan
}

\author{
Maulidatulfauziyah98@gmail.com
}

ABSTRAK

Tujuan dari artikel ini adalah menganalisis Pengaruh motivasi kerja, kepemimpinan, dan budaya perusahaan terhadap kepuasan kerja karyawan, dan pengaruhnya terhadap kinerja perusahaan. Hipotesis yang diajukan: Motivasi kerja berpengaruh signifikan terhadap kepuasan kerja karyawan, Kepemimpinan berpengaruh signifikan terhadap kepuasan kerja karyawan,Motivasi kerja berpengaruh signifikan terhadap kinerja perusahaan, Kepemimpinan berpengaruh signifikan terhadap kinerja perusahaan, Kepuasan kerja karyawan berpengaruh signifikan terhadap kinerja perusahaan. Hasil penelitian telah membuktikan bahwa motivasi kerja, kepemimpinan, dan budaya organisasi secara signifikan terkait dengan kepuasan kerja karyawan. Kepemimpinan, bagaimanapun, berhubungan negatif dengan kepuasan kerja karyawan. Motivasi kerja tidak signifikan terkait dengan kinerja perusahaan yang dipengaruhi oleh variabel intervening adalah kepuasan kerja karyawan. Dari hasil ini, ada dua kesimpulan utama yang dapat ditarik dalam penelitian ini. Pertama, motivasi kerja tidak dapat dihubungkan langsung dengan kinerja perusahaan jika tidak dihubungkan oleh variabel kepuasan kerja karyawan. Dan kesimpulan kedua adalah bahwa kepemimpinan berhubungan negatif dengan kepuasan kerja karyawan.

Kata kunci: motivasi kerja, kepemimpinan, kepuasan kerja karyawan, dan kinerja perusahaan.

\section{PENDAHULUAN}

Menurut (Ermita, 2012) dalam jurnalnya, Organisasi adalah wadah berkumpulnya sejumlah orang yang menja lankan aktivitas kerjanya masing-masing sesuai dengan tanggung jawab yang diberikan padanya. Pada dasarnya setiap organisasi memiliki sumber daya manusia yang berbeda-beda, baik dari segi kualitas maupun dari segi kuantitas.yang akan mempengaruhi perkembangan organisasi. sep erti: pimpinan, pegawai, program serta sarana dan prasarana. kesemua hal tersebut ikut menentu kan berhasil atau tidaknya pencapaian tujuan organisasi. Pegawai merupakan komponen yang memegang peranan utama dalam organisasi, karena pegawai bertanggung jawab unt uk kegiatan atau pelaksanaan program yang telah disusun. Disamping itu pegawai juga merupakan faktor utama (vital) dalam pelaksanaan tugas-tugas dan program-program yang telah ditetapkan organisasi

Lingkungan bisnis dewasa ini yang tumbuh dan berkembang dengan sangat dinamis, sangat memerlu-kan adanya sistem manajemen yang efektif dan efisien artinya dapat dengan mudah berubah atau menyesuaikan diri dan dapat mengakomodasikan setiap perubahan baik yang sedang dan telah terjadi dengan cepat, tepat dan terarah serta biaya yang murah. Dengan 
demikian, organisasi sudah tidak lagi dipandang sebagai sistem tertutup (closed-system) tetapi organisasi merupakan sistem terbuka (opened-system) yang harus dapat merespon dan meng-akomodasikan berbagai perubahan eksternal dengan cepat dan efisien.

Menciptakan kepuasan kerja karyawan adalah tidak mudah karena kepuasan kerja dapat tercipta jika variabel-variabel yang mempengaruhinya antara lain motivasi kerja, kepemimpinan dan budaya organisasi/ perusahaan dapat diakomodasikan dengan baik dan diterima oleh semua karyawan di dalam suatu organisasi/perusahaan. Kinerja organisasi tergantung dari kinerja individu atau dengan kata lain kinerja individu akan memberikan kontribusi pada kinerja organisasi, artinya bahwa perilaku anggota organisasi baik secara individu maupun kelompok memberikan kekuatan atas kinerja organisasi sebab motivasinya akan mempengaruhi pada kinerja organisasi.

Pemahaman motivasi, baik yang ada dalam diri karyawan maupun yang berasal dari lingkungan akan dapat membantu dalam peningkatan kinerja. Dalam hal ini seorang manajer perlu mengarahkan motivasi dengan menciptakan kondisi (iklim) organisasi melalui pembentukan budaya kerja atau budaya organisasi sehingga para karyawan merasa terpacu untuk bekerja lebih keras agar kinerja yang dicapai juga tinggi. Pemberian motivasi harus diarahkan dengan baik menurut prioritas dan dapat diterima dengan baik oleh karyawan, karena motivasi tidak dapat diberikan untuk setiap karyawan dengan bentuk yang berbedabeda.

Salah satu elemen yang bernilai penting dalam sistem manajemen perusahaan selain motivasi kerja kepada para karyawan adalah kepemimpinan (leadership). Hasil dari beberapa penelitian me-nunjukkan bahwa kepemimpinan sangat diperlukan untuk meningkatkan daya saing perusahaan secara berkelanjutan. Kepemimpinan adalah suatu proses dimana seseorang dapat menjadi pemimpin (leader) melalui aktivitas yang terus menerus sehingga dapat mempengaruhi yang dipimpinnya (followers) dalam rangka untuk mencapai tujuan organisasi atau perusahaan.

\section{PEMBAHASAN}

\section{Motivasi Kerja}

Dalam kehidupan berorganisasi, termasuk kehidupan ber-karya dalam organisasi bisnis, aspek motivasi kerja mutlak mendapat perhatian serius dari para manajer. Karena 4 (empat) pertimbangan utama yaitu: (1) Filsafat hidup manusia berkisar pada prinsip "quit pro quo", yang dalam bahasa awam dicerminkan oleh pepatah yang mengatakan "ada ubi ada talas, ada budi ada balas", (2) Dinamika kebutuhan manusia sangat kompleks dan tidak hanya bersifat materi, akan tetapi juga bersifat psikologis, (3) Tidak ada titik jenuh dalam pemuasan kebutuhan manusia, (4) Perbedaan karakteristik individu dalam organisasi atau perusa-haan, mengakibatkan tidak adanya satupun teknik motivasi yang sama efektifnya untuk semua orang dalam organisasi juga untuk seseorang pada waktu dan kondisi yang berbeda-beda.

Pemberian dorongan merupakan sebagai salah satu bentuk motivasi, penting dilakukan untuk meningkatkan gairah kerja karyawan sehingga dapat mencapai hasil yang dikehendaki oleh manajemen. Hubungan motivasi, gairah kerja dan hasil optimal mempunyai bentuk linear dalam arti dengan pemberian motivasi kerja yang baik, maka gairah kerja karyawan akan meningkat dan hasil kerja akan optimal sesuai dengan standar kinerja yang 
ditetapkan. Gairah kerja sebagai salah satu bentuk motivasi dapat dilihat antara lain dari tingkat kehadiran karyawan, tanggung jawab terhadap waktu kerja yang telah ditetapkan.

Terdapat 2 (dua) teknik memotivasi kerja pegawai yaitu: (1) Teknik pemenuhan kebutuhan pegawai, artinya bahwa pemenuhan kebutuhan pegawai meru-pakan fundamen yang mendasari perilaku kerja. (2) Teknik komunikasi persuasif, adalah merupakan salah satu teknik memotivasi kerja pegawai yang dilakukan dengan cara mempengaruhi pegawai secara ekstra logis. Teknik ini dirumuskan dengan istilah "AIDDAS" yaitu Attention (perhatian), Interest (minat), Desire (hasrat), Decision (keputusan), Action (aksi atau tindakan), dan Satisfaction (kepuasan). Penggunaannya, pertama kali pemimpin harus mem berikan perhatian kepada pegawai tentang pentingnya tujuan dari suatu pekerjaan agar timbul minat pegawai terhadap pelaksanaan kerja, jika telah timbul minat-nya maka hasratnya akan menjadi kuat untuk mengambil keputusan dan melakukan tindakan kerja dalam mencapai tujuan yang diharapkan oleh pemimpin. Dengan demikian, pegawai akan bekerja dengan motivasi tinggi dan merasa puas terhadap hasil kerjanya.

\section{Kepemimpinan}

Kepemimpinan itu adalah upaya mempengaruhi banyak orang melalui komunikasi untuk mencapai tujuan, cara mempengaruhi orang dengan petunjuk atau perintah, tindakan yang menyebabkan orang lain bertindak atau merespons dan menimbulkan peru-bahan positif, kekuatan dinamis penting yang memotivasi dan mengkoordinasikan organisasi dalam rangka mencapai tujuan, kemampuan untuk mencip-takan rasa percaya diri dan dukungan diantara bawahan agar tujuan organisasional dapat tercapai.

Peranan pemimpin atau kepemimpinan dalam organisasi atau perusahaan ada tiga bentuk yaitu peranan yang bersifat interpersonal, peranan yang bersifat informasional, dan peran pengambilan keputusan. Yang dimaksud dengan peranan yang bersifat interpersonal dalam organisasi adalah bahwa seorang pemimpin dalam perusahaan atau organisasi merupakan simbol akan keberadaan organisasi, seorang pemimpin bertanggung jawab untuk memo-tivasi dan memberikan arahan kepada bawahan, dan seorang pemimpin mempunyai peran sebagai penghubung. Peranan yang bersifat informasional mengandung arti bahwa seorang pemimpin dalam organisasi mempunyai peran sebagai pemberi, penerima dan penganalisa informasi. Sedangkan peran pemimpin dalam pengambilan keputusan mempunyai arti bahwa pemimpin mempunyai peran sebagai penentu kebijakan yang akan diambil berupa strategi-strategi bisnis yang mampu untuk mengem-bangkan inovasi, mengambil peluang atau kesem-patan dan bernegosiasi dan menjalankan usaha dengan konsisten.

\section{Kepuasan Kerja}

kepuasan kerja merupakan bagian dari proses motivasi. Kepuasan anggota organisasi dapat dihubungkan dengan kinerja dan hasil kerja mereka serta imbalan dan hukuman yang mereka terima. Oleh karena itu, tingkat kepuasan kerja dalam organisasi dapat ditunjukkan dengan hasil seperti sikap anggota organisasi, pergantian pekerjaan anggota organisasi, kemangkiran atau absensi, keterlambatan, dan keluahan yang biasa terjadi dalam suatu organisasi. 
Ada 2 (dua) faktor yang mempengaruhi kepuasan kerja yaitu faktor yang ada pada diri pegawai dan faktor pekerjaannya. Faktor yang ada pada diri pegawai yaitu kecerdasan $(I Q)$, kecakapan khusus, umur, jenis kelamin, kondisi fisik, pendidikan, pengalaman kerja, masa kerja, kepribadian, emosi, cara berpikir, persepsi, dan sikap kerja. Sedangkan faktor pekerjaan yaitu jenis pekerjaan, struktur organisasi, pangkat (golongan), kedudukan, mutu pengawasan, jaminan keuangan, kesempatan promosi jabatan, interaksi sosial, dan hubungan kerja.

\section{Kinerja}

Setiap manusia mempunyai potensi untuk bertindak dalam berbagai bentuk aktivitas. Kemam-puan bertindak itu dapat diperoleh manusia baik secara alami (ada sejak lahir) atau dipelajari. Walau-pun manusia mempunyai potensi untuk berperilaku tertentu tetapi perilaku itu hanya diaktualisasi pada saat-saat tertentu saja. Potensi untuk berperilaku tertentu itu disebut ability (kemampuan), sedangkan ekspresi dari potensi ini dikenal sebagai performance (kinerja).

Menurut (Ermita, 2019) dalam jurnalnya, keberhasilan suatu organisasi dalam mencapai tujuan tidak terlepas dari faktor sumber daya manusianya. Istilah sumber daya manusia dapat disamakan artinya dengan pegawai atau karyawan, yaitu orang yang mengerjakan suatu pekerjaan dalam suatu organisasi, baik organisasi yang bergerak dalam bidang pemerintahan maupun bidang swasta. Setiap pegawai dalam organisasi tentunya memiliki tugas dan tanggung jawab yang harus dilaksanakan sesuai dengan tuntutan organisasi atau lembaga. Baik atau buruknya pekerjaan seorang pegawai dapat dilihat dari kinerjanya.

Kinerja pegawai tidak hanya sebagai hasil kerja yang telah dicapai oleh seorang pegawai dalam suatu organisasi, namun kinerja juga merupakan suatu proses bagaimana pekerjaan pegawai tersebut berlangsung sehingga mencapai hasil kerja yang diharapkan.

Kinerja adalah suatu hasil kerja yang dicapai seorang dalam melaksanakan tugastugas yang dibebankan kepadanya yang di-dasarkan atas kecakapan, pengalaman dan kesungguhan serta waktu. Dengan kata lain bahwa kinerja adalah hasil kerja yang dicapai oleh seseorang dalam melaksanakan tugas yang diberikan kepadanya sesuai dengan kriteria yang ditetapkan. Kinerja seseorang merupakan ukuran sejauh mana keberhasilan seseorang dalam melakukan tugas pekerjaannya. Ada 3 (tiga) faktor utama yang berpengaruh pada kinerja yaitu individu (kemampuan bekerja), usaha kerja (keinginan untuk bekerja), dan dukungan organisasional (kesempatan untuk bekerja).

Ada 4 (empat) unsur-unsur yang. terdapat dalam kinerja adalah hasil-hasil fungsi pekerjaan, faktor-faktor yang berpengaruh terhadap prestasi karyawan, pencapaian tujuan organisasi, dan periode waktu tertentu.

\section{Pengaruh Motivasi Kerja terhadap Kepuasan Kerja Karyawan}

Motivasi kerja berpengaruh terhadap kepuasan kerja karyawan, artinya bahwa motivasi kerja memang sangat diperlukan oleh seorang karyawan untuk dapat mencapai suatu kepuasan kerja yang tinggi meskipun menurut sifatnya kepuasan kerja itu sendiri besarannya sangat relatif atau berbeda antara satu orang dengan orang lainnya. Tetapi secara keseluruhan, para responden menyatakan bahwa selama bekerja di perusahaan mereka 
menyatakan merasa puas atas motivasi kerja yang selama ini diberikan oleh manajemen kepada para karyawan perusahaan.

\section{Pengaruh Kepemimpinan terhadap Kepuasan Kerja Karyawan}

Menurut (Ermita, 2012) dalam jurnalnya, Agar penyampaian intruksi atau perintah, petunjuk, arahan, bimbingan dan pembinaan kepada pegawai dalam mel aksanakan tugas dapat diterima dengan baik dalam arti mau menerima apa yang ditugas kan oleh atasan dalam hal ini pimpinan, ma ka perlu adanya hubungan yang baik antara ke dua belah pihak. Tanpa adanya hubungan baik antara pimpinan dengan pegawai, maka sulit terciptanya kerja sama yang baik dalam melaksa nakan tugas. Oleh sebab itu antara pimpinan deng an pegawai perlu melakukan komunikasi yan g baik dalalam rangka menciptakan hubungan yang harmonis bagi kedua belah pihak dalam melaksanakan tugas dan fungsi masing-masing di dalam organisasi.

Kepemimpinan berpengaruh terhadap kepuasan kerja karyawan, artinya hasil dari pelaksanaan aktivitas manajerial kepemimpinan yang dijalankan belum tentu mempunyai dampak yang selalu positif atau baik bagi organisasi, sebab semakin tinggi pelaksanaan aktivitas manajerial kepemim-pinan dilakukan, maka akan berdampak pada penurunan kinerja perusahaan dari waktu ke waktu. Pelaksanaan aktivitas kepemimpinan yang lebih banyak ke arah menekan karyawan bisa saja menyebabkan seorang karyawan dapat mencapai kepuasan dalam bekerja, tetapi belum tentu dapat membawa pengaruh yang positif dalam pembentukan kepribadian bawahan untuk ikhlas bekerja mencapai tujuan organisasi.

\section{Pengaruh Motivasi Kerja terhadap Kinerja Perusahaan}

Motivasi kerja berpengaruh terhadap kinerja perusahaan, artinya meskipun motivasi kerja berpengaruh positif dan signifikan terhadap kepuasan kerja tetapi belum tentu mempengaruhi kinerja perusahaan. Hal ini dapat terjadi karena karyawan yang merasa puas karena telah dipenuhi kebutuhannya oleh manajemen dapat bekerja secara optimal. Belum optimalnya kerja seorang karyawan dibatasi oleh adanya kebijakan atasan misalnya berhubungan dengan waktu lembur, yaitu karyawan yang telah terpuaskan kebutuhannya merasa bahwa manajemen telah memberikan penghargaan kepada dirinya sehingga dia merasa harus bekerja dengan profesional artinya apabila terdapat pekerjaan yang melekat pada dirinya yang sampai dengan jam kerja belum selesai tetapi dapat diselesaikan hari tersebut, karyawan tersebut bermaksud untuk menyelesaikannya karena dedikasi dan loyalitas terhadap pekerjaannya meskipun tidak diperhitungkan waktu lembur. Tetapi pihak manajemen menentukan bahwa sesuai ketentuan yang ada hal tersebut tidak diperkenankan, akhirnya karyawan tersebut akan menyelesaikan pada hari berikutnya. Hal inilah yang salah satunya menjadi suatu per-timbangan dan alasan bahwa motivasi kerja berpengaruh signifikan terhadap kepuasan kerja tetapi motivasi kerja tidak berpengaruh signifikan terhadap kinerja perusahaan.

\section{Pengaruh Kepemimpinan terhadap Kinerja Perusahaan}

Kepemimpinan berpengaruh terhadap kinerja perusahaan, artinya kepemimpinan merupakan suatu upaya untuk memengaruhi banyak orang melalui proses komunikasi untuk mencapai tujuan organisasi diharapkan dapat menimbulkan perubahan positif berupa 
kekuatan dinamis yang dapat mengkoordinasikan organisasi dalam rangka mencapai tujuan jika diterapkan sesuai dengan koridor yang telah ditetapkan kedua belah pihak sesuai dengan jabatan yang dimiliki.

\section{Pengaruh Kepuasan Kerja Karyawan terhadap Kinerja Perusahaan}

Kepuasan kerja karyawan berpengaruh terhadap kinerja perusahaan, artinya bahwa secara umum kepuasan kerja karyawan yang tinggi akan mampu meningkatkan kinerja perusahaan.

\section{KESIMPULAN}

Pemberian dorongan merupakan sebagai salah satu bentuk motivasi, penting dilakukan untuk meningkatkan gairah kerja karyawan sehingga dapat mencapai hasil yang dikehendaki oleh manajemen. Hubungan motivasi, gairah kerja dan hasil optimal mempunyai bentuk linear dalam arti dengan pemberian motivasi kerja yang baik, maka gairah kerja karyawan akan meningkat dan hasil kerja akan optimal sesuai dengan standar kinerja yang ditetapkan. Gairah kerja sebagai salah satu bentuk motivasi dapat dilihat antara lain dari tingkat kehadiran karyawan, tanggung jawab terhadap waktu kerja yang telah ditetapkan.

Kepemimpinan itu adalah upaya mempengaruhi banyak orang melalui komunikasi untuk mencapai tujuan, cara mempengaruhi orang dengan petunjuk atau perintah, tindakan yang menyebabkan orang lain bertindak atau merespons dan menimbulkan peru-bahan positif, kekuatan dinamis penting yang memotivasi dan mengkoordinasikan organisasi dalam rangka mencapai tujuan, kemampuan untuk mencip-takan rasa percaya diri dan dukungan diantara bawahan agar tujuan organisasional dapat tercapai.

Motivasi kerja berpengaruh terhadap kepuasan kerja karyawan, artinya bahwa motivasi kerja memang sangat diperlukan oleh seorang karyawan untuk dapat mencapai suatu kepuasan kerja yang tinggi meskipun menurut sifatnya kepuasan kerja itu sendiri besarannya sangat relatif atau berbeda antara satu orang dengan orang lainnya. Tetapi secara keseluruhan, para responden menyatakan bahwa selama bekerja di perusahaan mereka menyatakan merasa puas atas motivasi kerja yang selama ini diberikan oleh manajemen kepada para karyawan perusahaan.

Kepemimpinan berpengaruh terhadap kepuasan kerja karyawan, artinya hasil dari pelaksanaan aktivitas manajerial kepemimpinan yang dijalankan belum tentu mempunyai dampak yang selalu positif atau baik bagi organisasi, sebab semakin tinggi pelaksanaan aktivitas manajerial kepemim-pinan dilakukan, maka akan berdampak pada penurunan kinerja perusahaan dari waktu ke waktu. Pelaksanaan aktivitas kepemimpinan yang lebih banyak ke arah menekan karyawan bisa saja menyebabkan seorang karyawan dapat mencapai kepuasan dalam bekerja, tetapi belum tentu dapat membawa pengaruh yang positif dalam pembentukan kepribadian bawahan untuk ikhlas bekerja mencapai tujuan organisasi. 


\section{DAFTAR RUJUKAN}

Ayu, I., \& Suprayetno, A. (2008). Pengaruh Motivasi Kerja, Kepemimpinan Terhadap Kepuasan Kerja Karyawan serta Dampaknya pada Kinerja Perusahaan. Jurnal Manajemen Dan Kewirausahaan, 10(2), 124-135. https://doi.org/10.9744/jmk.10.2.pp.124-135

Ermita. (2012). Hubungan Antar Manusia dan Semangat Kerja Pegawai. Jurnal Pedagogi, 12(2), 70-81.

Ermita. (2019). PEMBINAAN KINERJA PEGAWAI OLEH PIMPINAN ATASAN LANGSUNG DI KANTOR KEMENTERIAN AGAMA KOTA BUKITTINGGI. Jurnal Bahana Manajemen Pendidikan, 8. 